\title{
The Renatura sea turtle conservation program in Congo
}

\author{
Alexandre Girard ${ }^{1 *}$ \& Nathalie Breheret ${ }^{2 *}$ \\ 1 Renatura France \\ *agirard@gmail.com \\ 2 Renatura Congo \\ *natbreheret@yahoo.fr
}

\section{ABSTRACT}

Renatura, is a non profit organization protecting and studying sea turtles in Congo-Brazzaville. Congo waters host five species of sea turtles. The leatherback turtle and the olive ridley turtle come to nest on Congo beaches from September to April. Juvenile Green turtles and Hawksbill turtles are also feeding and growing nearshore. Main threats weighing on sea turtles in Congo are i) egg harvesting and female poaching, ii) by-catch in both traditional and industrial fishing gears, iii) erosion of beaches, iv) urban/industrial development of the coastline. To fight against these threats, Renatura has developed a nest monitoring program and a by-catch release program. More than 1,500 sea turtles incidentally caught in traditional fishing nets are released every year. To find a reliable solution on the long term, a study is in progress to design fishing gears and practices able to reduce the by-catch risk. Nest monitoring and release programs did not improve the trends of sea turtles populations in Congo. Eight years of follow-up shows a dramatic decrease of leatherback and olive ridley nesting activities on the Congo's beaches. To try to improve this situation, a new program has been launched in 2010 to address by-catches in industrial fishing nests.

KEY WORDS: Sea turtles, Republic of Congo, Dermochelys coriacea, Lepidochelys olivacea, Chelonia mydas, Eretmochelys imbricata, bycatch, Renatura, wildlife conservation.

\section{RESUMEN}

Renatura es una organización sin ánimo de lucro para la protección y el estudio de tortugas marinas en Congo-Brazzaville. Las aguas congoleñas albergan cinco especies de tortugas marinas. La tortuga laúd y la tortuga olivácea anidan en las playas de Congo entre septiembre y abril. Los juveniles de tortugas verde y carey se alimentan y crecen también en las aguas costeras. Los peligros que acechan a estas especies en esta zona son: el saqueo de nidos y robo de huevos, la captura accidental tanto en la pesca artesanal como en la industrial, la erosión de las playas de anidación y la construcción desmesurada, tanto industrial como urbana, en el litoral. Para hacer frente a estos peligros, Renatura ha puesto en marcha diversos mecanismos, como el programa de monitoreo de anidación y también el programa de liberación de las capturas accidentales. Más de 1500 tortugas son liberadas cada año, con la ayuda de los pescadores artesanales que participan en el programa de liberación de las capturas accidentales. Para encontrar una solución definitiva al problema, se está llevando a cabo un estudio sobre aparejos y prácticas pesqueras que reduzcan el riesgo de captura accidental. Los programas puestos en marcha en Congo, tanto el monitoreo de nidos como el de liberación de las capturas, no han mejorado la tendencia de las poblaciones de tortugas marinas en Congo. El seguimiento de los últimos ocho años indica un decrecimiento dramático de la anidación de laúdes y loras en estas playas. Para intentar mejorar esta situación acaba de ponerse en marcha en 2010 un nuevo programa para disminuir la captura accidental en la pesquería industrial.

PALABRAS CLAVES: Tortugas marinas, República del Congo, Dermochelys coriacea, Lepidochelys olivacea, Chelonia mydas, Eretmochelys imbricata, captura accidental, Renatura, conservación de vida silvestre.

\section{LABURPENA}

Renatura, itsas dortoken ikerketa eta babeserako Kongo-Brazzavillen sortutako irabazi gabeko elkartea da. Kongoko itsas eremuak, bost itsas dortoka espezie ezberdinei egiten die harrera, hauetako bik bertan dituzte errute hondartzak: larruzko dortoka eta oliba dortokak Iraila eta Apirila bitartean hain zuzen ere. Bestalde, karei eta dortoka berde gazteak kostako uretan elikatu eta hazten dira. Inguru honetan espezie guzti hauek pairatzen dituzten arriskuak asko dira: habien arrapaketa eta arraultzen lapurreta, arrantza artisauaren baita industrialaren harrapaketa akzidentala, errute hondartzen higadura eta itsas bazterrean osoan zehar ematen ari den neurriz kanpoko erainkuntza bai industrial baita urbanoa ere. Arrisku hauei aurre egin ahal izateko, Renaturak zenbait egitasmo jarri ditu abian, hala nola: errute garaiko monitoreo programa, baita dortoken arrantza akzidentalean eroritako aleen askapenak. Azken honetan urtero urtero 1500 dortoka baino gehiago askatzen dira arrantza tradizionalean jarduten diren arrantzaleen laguntzaz. Arazo honi behin betiko konponbidea emateko, arrantza teknika aparailuak eta praktikak ikertzen hasiak dira.

GAKO-HITZAK: Itsas dortokak, Kongoko Errepublika, Dermochelys coriacea, Lepidochelys olivacea, Chelonia mydas, Eretmochelys imbricata, arrantza akzidentala, Renatura, basa bizitzaren kontserbazioa.

\section{INTRODUCTION}

Renatura is a NGO that was created in France in 2001 and in 2005 in the Republic of Congo (Congo-Brazzaville, hereafter Congo). Renatura's main goal is sea turtle conservation. It promotes sea turtle protection and research, through local sustainable development in Congo.

The Republic of Congo is a country in Central Africa, surrounded by Gabon, Cameroon, the Central African Republic, the Democratic Republic of Congo (DRC) and An- gola. The Congolese coastline stretches for $170 \mathrm{~km}$ and its waters host five species of sea turtles. Two sea turtle species nest regularly on Congo's beaches: the leatherback Dermochelys coriacea (Vandelli, 1761) and the olive ridley Lepidochelys olivacea (Eschscholtz, 1829). Thousands of green turtles Chelonia mydas (Linnaeus, 1758) - mainly juveniles and subadults - are present at sea, as well as hundreds of hawksbill turtles Eretmochelys imbricata (Linnaeus, 1766) and some occasional loggerheads Caretta caretta (Linnaeus, 1758). 


\section{THREATHS AFFECTING SEA TURTLES IN CONGO}

Sea turtles in Congo are exposed to many threats, mostly linked to human activities: (1) Nesting females are hunted for their meat, (2) eggs are collected from nests and (3) to a lesser extent, turtles are also used to produce handicraft on shells and for traditional medicine.

Some indirect threats are also weighing on sea turtles in Congo, such as coastal development, and pollution by industrial and domestic wastes. Sea turtle are often captured incidentally in fishing gear of traditional and industrial fisheries.

\section{REGULATORY ARSENAL IN CONGO}

The Republic of Congo voted a new law in November 2008 to manage wildlife resources. Renatura participated in the government discussions regarding this list, advocating for the inclusion of all marine turtle species present in the country.

An application decree published in April 2011 ( $n^{\circ} 6075$, April 9, 2011) details the list of animals fully or partially protected by this law. All the sea turtles species are now fully protected in Congo.

The Congo has signed international conventions dealing with sea turtle protection: The Convention on the Conservation of Migratory Species of Wild Animals (CMS-Bonn convention), the Convention on International Trade in Endangered Species of Wild Fauna and Flora (CITES), the Memorandum of Understanding Concerning Conservation Mesures for Marine Turtles of the Atlantic Coast of Africa, Abidjan, Côte d'Ivoire (1999).

Unfortunately, law enforcement is very poor in Congo and international conventions have not been transposed in national laws.

Congolese traditional beliefs represent another lever to protect sea turtles. For example, in ancient times sea turtles were respected in the local Vili culture since they were considered the soul of the sea world.

\section{RENATURA ACTIONS}

Since 2001, Renatura has been active in several different ways: (1) Protection and research both on nesting beaches and off shore, (2) Intensive environmental awareness and education sessions in schools, and (3) development of a community based eco-tourism program.

\section{Nesting site protection and follow-up Protection}

Since 2003, Renatura field teams have been conducting daily patrols during the nesting season at two strategic sites for leatherback and olive ridley nesting. The goal is to collect accurate data to permit the description of leatherback and olive ridley nesting in Congo and to ensure protection of females, nests and hatchlings on the beaches. In addition, the permanent presence of field technicians drastically reduces human predation. Ten years ago, human predation rate was as much as $100 \%$. Today, the presence of field teams (Congolese employees recruited among fishermen in local villages), combined with outreach and education has led to a decrease of hunting and harvesting activities to less than $5 \%$.

\section{Assessing overall sea turtle nesting activities in Congo}

Non-intensive surveys of nesting activities are undertaken at three additional sites, where a dedicated team carries out regular nest counts once every three weeks. Daily monitoring and non-intensive survey sites are evenly spaced along the coastline. Thanks to the coIlaboration with Prof. Marc Girondot of France's Orsay University, data from intensive and non-intensive monitoring were used to model the nesting seasons' trends (GODGENGER et al., 2009). In fact, modelling can be used to assess nesting abundance along the entire Congolese coastline and to determine trends for leatherback and olive ridley nesting over time.

Analysis of a seven-year dataset, shows a dramatic decrease of olive ridley nest numbers on Congolese beaches (Fig. 1A, 1B), despite Renatura's activities and our unquestionable success in terms of decreasing egg harvesting and female hunting. A longer-term survey is needed to discern trends in leatherback nesting activity.

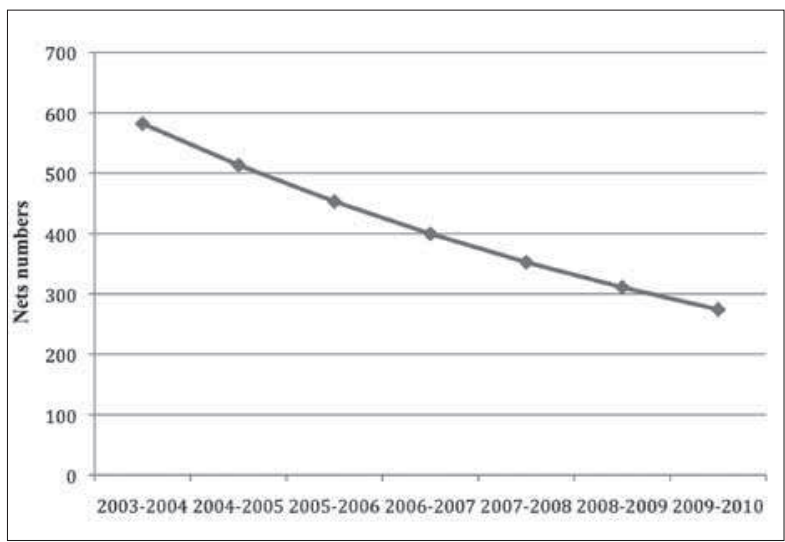

Fig. 1A.- Olive ridley nesting trend on Congo beaches (2003-2010).

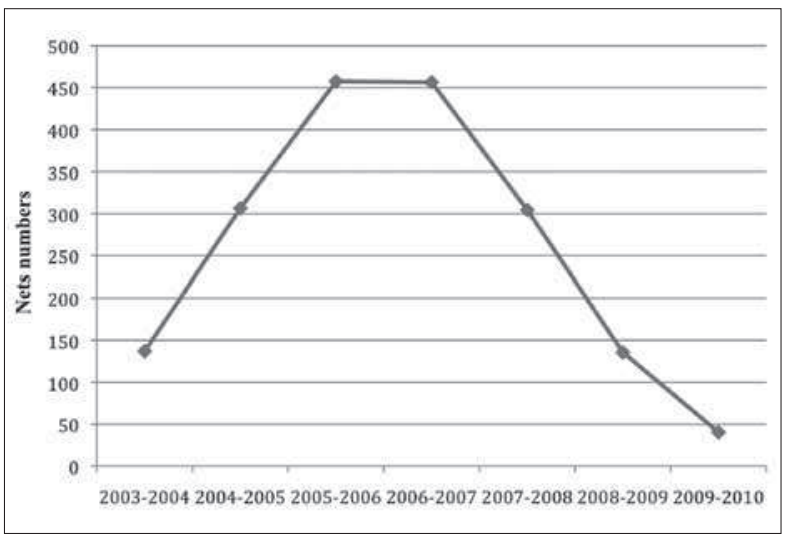

Fig. 1B.- Leatherback nesting trend on Congo beaches (2003-2010). 


\section{Environmental education}

Outreach and education about the environment in general and sea turtles in particular are important priorities of our conservation work. Since 2005, Renatura has developed an environmental education program in coastal villages and in the town of Pointe Noire (the main harbour and the biggest town of Congo). Awareness is raised among adults thanks to mobile exhibitions, movie projections, conferences in town halls and marketplaces.

To bring environmental education to children and youth, the actors of tomorrow's Congolese society, our education team implements interactive methods in private and public schools and through leisure activities in coastal villages during holidays (Fig. 1). Every session is built according to the David Kolb pedagogical method, based on interaction and adapting the information delivery to each type of learner. A large variety of activities are implemented in each session (working groups, testimonies, theatre sketches, games) (Fig. 2, 3). Results are assessed through questionnaires undertaken before and after each education session. In addition, during summer holidays the Renatura education staff organises environmental games and leisure activities in remote villages for children and youth, as well as movie projections at night.

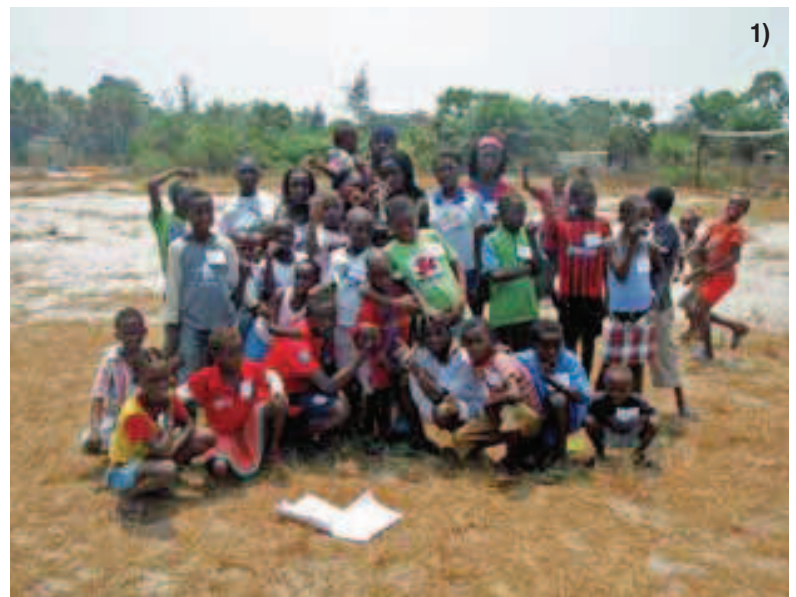

Fig. 1, 2, 3.- Leisure activities in coastal villages during holidays.

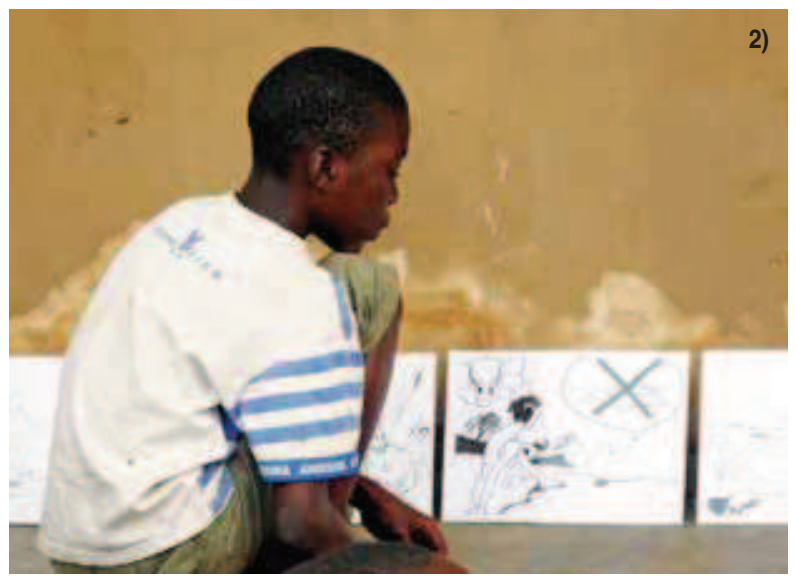

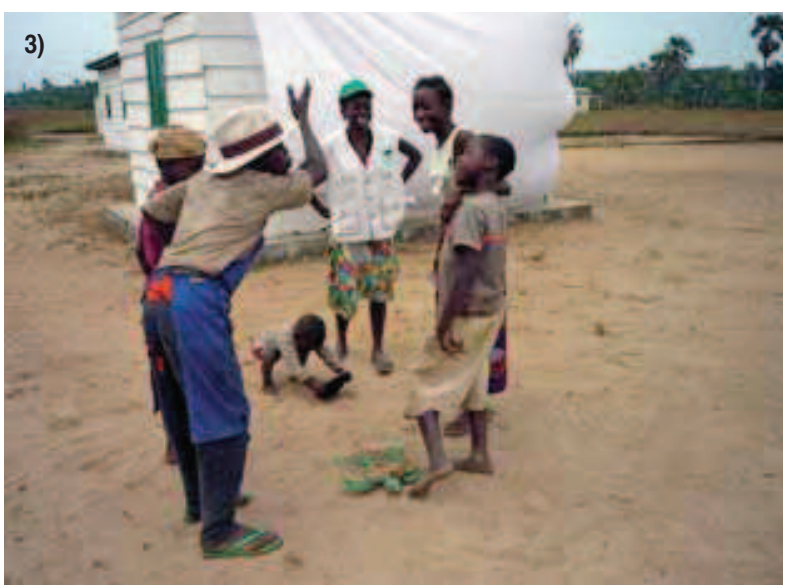

\section{Release of turtles accidentally caught in fishing nets}

Each year, high numbers of sea turtles are incidentally caught in fishing nets, (Fig. 4) mainly gill nets. Previously turtle meat used to be sold in market places to compensate for the cost of fixing the fishing nets damaged by turtles. From 2005, Renatura has developed - in collaboration with fishermen - a community-based program to accompany them in the release of incidentally captured turtles.

Renatura has implemented a release process when a turtle is captured in a traditional fishing net. Fishermen contact the Renatura release team. The team goes on site to check if the capture is real and if the turtle is alive and in good condition. Field technicians in charge of this program also collect data about the capture, take measurements and tag the turtle before releasing it.

Damage to the fishing nets is evaluated by Renatura's team, which is composed of local employees who where previously fishermen. In return for releasing the turtle, Renatura provides the necessary amount of net line bobbin (for little damage) or net pieces (in the case of a large damage) to fix the fishing gear (Fig. 5)

Thanks to this program, more than 1500 turtles have been released each year since 2005 (Fig. 6, 7, 8). The importance of the release program is manifold:

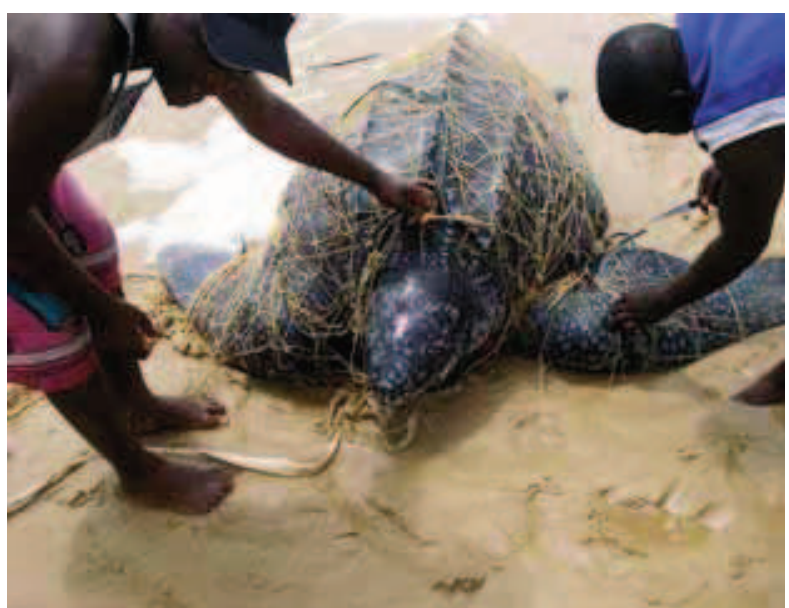

Fig. 4.- Leatherback cought in the fishing net. 


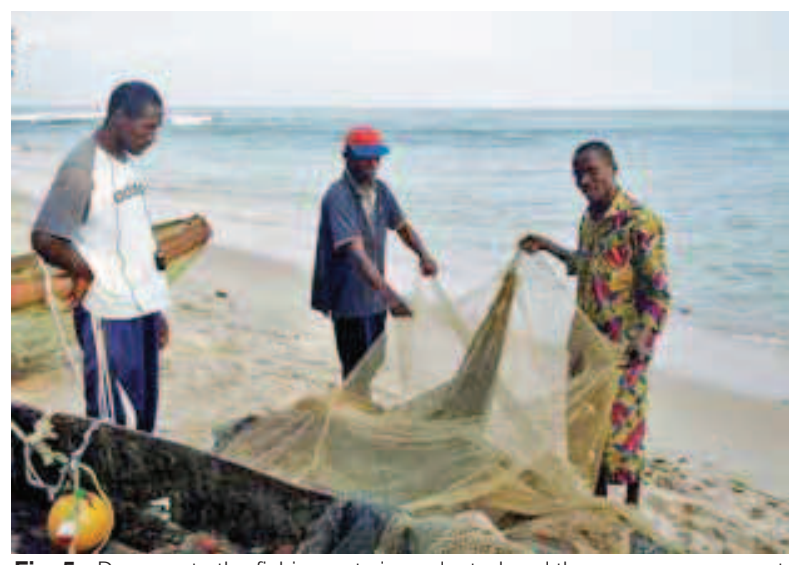

Fig. 5.- Damage to the fishing nets is evaluated and the necessary amount of net provided.

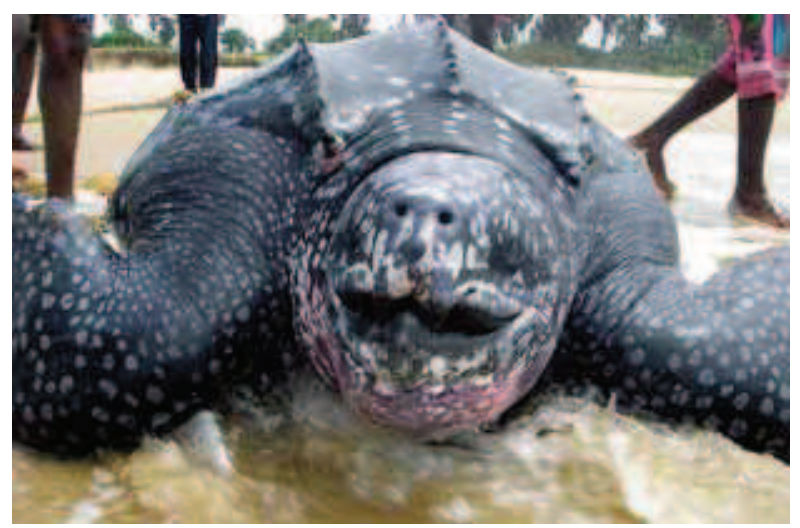

Fig. 6.- Release of a leatherback turtle accidentally caught in fishing nets.

- Implements concrete actions to reduce sea turtle loss due to bycatch in artisanal fisheries;

- Reduces commercialisation of turtles;

- Motivates fishermen to become responsible for the sustainable management of their natural resources;

- Enables tracking of by-caught turtles through recaptures, each individual being tagged, identified and measured before release.

Thanks to the release program, a large set of data has been collected throughout the year on four species of sea turtles, including juveniles, sub-adults, adult females and males (Table 1). Results from the release program highlight the presence of an important feeding ground and a developmental area in Loango Bay for green and hawksbill turtles.

\section{Ecotourism}

Since May 2009, Renatura proposes several tourist activities to discover sea turtles in the field. A portion of the income from tourism is used to fund some of the NGO activities. The other portion is used to promote micro-projects chosen by the local communities. This programme has already enabled one of the villages to fix a water-

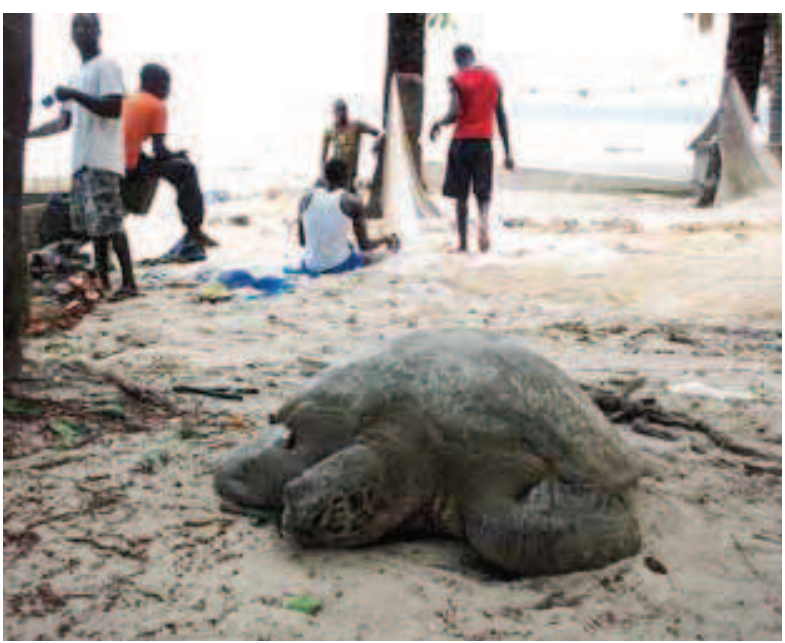

Fig. 7.- Green turtle accidentally caught in a fishing net waiting for its liberation.

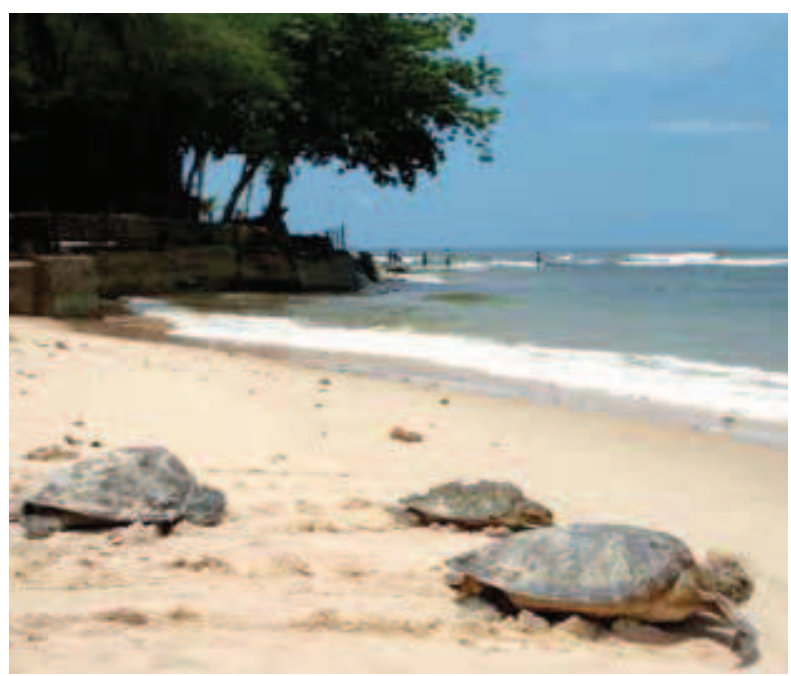

Fig. 8.- Release of green turtles accidentally caught in fishing nets.

\begin{tabular}{|lc|}
\hline Total recorded capture events & 9044 \\
\hline Of known species & 9035 \\
\hline Releases & 8133 \\
\hline Unreleased & 902 \\
\hline \multicolumn{2}{l}{ Captured Chelonia mydas } \\
\hline Released & 5842 \\
\hline Captured Dermochelys coriacea & 5438 \\
\hline Released & 1185 \\
\hline Captured Lepidochelys olivacea & 1045 \\
\hline Released & 1551 \\
\hline Captured Eretmochelys imbricata & 1270 \\
\hline Released & 457 \\
\hline
\end{tabular}

Table 1.- Sea turtle capture events recorded by Renatura (2005-2010) in the Republic of Congo.

pump and ensure a regular water supply. School books were also purchased for the local school. Thanks to this approach, sea turtles are thus considered a value for the community. 


\section{Future development}

Renatura has recently already launched two new projects,

- Development and testing, with local fishermen, of alternative fishing techniques and gears (shape of the net, depth, fishing hours and methods, etc.) to reduce incidental capture in the long term.

- Further studies on the Loango bay feeding ground. Renatura plans to create a marine protected area managed with local communities.

In the near future, we will also develop a program to reduce incidental by-catch by industrial fishing vessels. In fact, the observed decrease of olive ridley nesting, despite the encouraging conservation results Renatura has obtained on the beaches, could be due to sea turtle by-catch in industrial fishing gear. A large number of industrial fishing boats operate in Congolese waters, some are legal but others are fishing illegally (without authorisation, without a flag, or using illegal fishing techniques such as paired boats or proximity to the shore).

An initial meeting with legal industrial boat owners will be held in Pointe Noire during the first half of 2011 to launch a study on sea turtle and cetacean by-catch by trawlers and industrial fishing gear in Congolese waters, and to raise awareness among fishing boats owners.

A second phase will involve:

- encouraging industrial fisheries to adopt techniques reducing by-catch, such as Turtle Excluder Devices.

- and fighting against Illegal Unregulated Unreported (IUU) Fishing.

\section{ACKNOWLEDGEMENTS}

We thank our financial supporters: USFWS, Fondation Nature et découvertes, FFEM, and our local funders: ENI, MAG Industries, Dietsmann, Tractafric, Puma, CFAO, Chevron, Boscongo, as well as the association Afrique Troisième Millénaire.

\section{BIBLIOGRAPHY}

Breheret, N., Adell, M., Bal, G., Ndamite, K., Fasouel, P., Girard, A. 2010. Follow-up and release of the incidental capture of marine turtles in traditional fishing nets: a community based program in the Republic of Congo. In: 30 th Annual Symposium on Sea Turtle Biology and Conservation, Goa, India. April, 2010.

Girard, A., Bréheret, N., Adell, M., N'Daminté, K., Fasquel, P., BAL, G., GIRONDOT, M. 2010. New facts on sea turtles in the Republic of Congo according to the analysis of the data collected on the sea turtle incidental captures. In: 30 th Annual Symposium on Sea Turtle Biology and Conservation, Goa, India. April, 2010.

Girard, A., Breheret, N., Bal, G., Ndamite, K. 2010. RENATURA marine turtles conservation program in Congo. In: $28^{\text {th }}$ Annual Symposium on Sea Turtle Biology and Conservation. K. Dean, M. López-Castro (Compilers): 83. NOAA Technical Memorandum NOAA NMFS-SEFSC-202. Miami.

Godgenger, M-C, Bréheret, N., Bal, G., N'DAmité, K., GirARD, A., GIRONDOT, M. 2009. Nesting estimation and analysis of threats for Critically Endangered leatherback Dermochelys coriacea and Endangered olive ridley Lepidochelys olivacea marine turtles nesting in Congo. Oryx 43: 556-563. 